\title{
A suggestion that Europe also a Muslim: a study from historical and contemporary perspectives
}

\author{
Muhammad Aiman Awaluddin \\ Business School, Sakarya University, Turkey \\ E-mail:muhammed.awaluddin@ogr.sakarya.edu.tr
}

\author{
Anisa Safiah Maznorbalia \\ Ghazali Shafie Graduate School of Government, Universiti Utara Malaysia \\ E-mail:anisa.safiah@gmail.com
}

DOI: $10.18326 /$ ijims.v9i1. 83-110

\begin{abstract}
In the past century saw that Europe associates themselves as a Christian domain until now. The proclaimation of Edict of Thessalonica in $380 \mathrm{AD}$ made the Nicene Christianity as the state in Roman Empire and saw a transition from paganism to a Christian domain or Christendom. Since its inception, several edict has been enacted and several peace treaties have been broken to diminish an idea of multiculturalism within theirs faith land. The establishment of Muslim rules in Iberian Peninsula has changed the dominion of Christian. Muslims in Spain introduced convivencia, which saw that Abrahamic religions, Islam, Judaism and Christianity co-exist together, removing racial, cultural and religious barriers to embrace each other that nurture spirit of inclusion. The Golden Age of Muslim Civilization evidence that Cordova has become a center of Europe, perhaps the world for scientific knowledge advancement. Subsequently, contribute for Renaissance Age in Europe. Additionally, fall of Constantinople in 1453 under
\end{abstract}


Ottomans reshaping the geographcial of Europe and permanently marked the term of European Islam. Through tedious analysis on medias, reports and past journals, this article adopted critical analysis in understanding the complexity of history of Europe, at the same time positioning Islam as part of Europe culture. The contribution of Islam in Europe seems negligible and less attention has been given. Past researchers tend to overlooked and belittled impacts of Islam in Europe continent, thus diminish any legitimacy of Islam in Europe. Critical analysis methodology assist researcher to understand the main issues, reviewing past and present evidence from reliable sources to establish concrete arguments in providing critical evaluation on the discussed issues. It is also a form of method involve investigating topics more deeply, by going beneath the surface of reality to explore the truth of a particular issue. The article established it arguments through historical analysis in Europe starting from ancient time to present situation to give a clear analogy and legitimacy on the presence of Islam in Europe. The finding shows that Islam indeed part of Europe since establishment of Umayyad Caliphate and presence of Islam in Sicily. Moreover, contemporarily, the rising of Muslims, issues of atheism and secularism proof that Europe is no longer center of Christianity but already become multiculturalism society.

Pada abad lalu, Eropa mengasosiasikan diri mereka sebagai sebuah domain Kristen sampai sekarang. Maklumat Edict of Thessalonica pada 380 AD menjadikan Kekristenan Nicene sebagai negara di dalam Imperium Romawi dan melihat peralihan dari paganisme kepada suatu domain Kristen atau Kekristenan. Sejak didirikan, beberapa dekrit telah diberlakukan dan beberapa perjanjian damai telah dipatahkan untuk mengurangi gagasan multikulturalisme di dalam tanah kepercayaan mereka. Pendirian aturan Muslim di Semenanjung Iberia telah mengubah kekuasaan Kristen. Muslim di Spanyol memperkenalkan convivencia, yang melihat bahwa agama Abrahamik, Islam, Yudaisme dan Kristen hidup berdampingan bersama-sama, menghilangkan hambatan rasial, budaya dan agama untuk merangkul satu sama lain yang memupuk semangat inklusi. Zaman keemasan peradaban Muslim membuktikan bahwa Cordova telah menjadi pusat Eropa dan mungkin dunia untuk kemajuan pengetahuan ilmiah. Selanjutnya, berkontribusi untuk Renaissance Age di Eropa. Selain itu, jatuhnya Konstantinopel pada tahun 1453 di bawah Ottomans membentuk 
kembali geografi Eropa dan secara permanen menandai istilah Islam Eropa. Melalui analisa yang membosankan tentang media, laporan dan jurnal masa lalu, artikel ini mengadopsi analisa kritis dalam memahami kompleksitas sejarah Eropa, pada saat yang sama memposisikan Islam sebagai bagian dari budaya Eropa. Kontribusi Islam di Eropa tampaknya diabaikan dan kurang mendapatkan perhatian. Peneliti masa lalu cenderung mengabaikan dan meremehkan dampak Islam di benua Eropa, sehingga mengurangi legitimasi Islam di Eropa. Metodologi analisis kritis membantu peneliti untuk memahami isu utama, meninjau bukti-bukti masa lalu dan sekarang dari sumber terpercaya untuk membangun argumen konkret dalam memberikan evaluasi kritis pada masalah yang dibahas. Ini juga merupakan bentuk metode yang melibatkan penyelidikan topik lebih dalam, dengan menjangkau bagian bawah dari permukaan realitas untuk mengeksplorasi kebenaran dari masalah tertentu. Artikel itu menetapkan argumen melalui analisis sejarah di Eropa mulai dari zaman kuno untuk menyajikan situasi dan memberikan analogi yang jelas dan legitimasi di hadapan Islam di Eropa. Temuan ini menunjukkan bahwa Islam memang bagian dari Eropa sejak berdirinya kekhalifahan Umayyah dan kehadiran Islam di Sisilia. Selain itu, bersamaan dengan meningkatnya umat Islam, isu ateisme dan sekularisme merupakan bukti bahwa Eropa tidak lagi menjadi pusat Kekristenan tetapi sudah menjadi masyarakat multikulturalisme.

Keywords: European History; European Islam; Multiculturalism; Muslim Civilization

\section{Introduction}

Since ancient times, Europe has been associated as Christian domain, infamously known as Christendom. ${ }^{1}$ Christian beliefs and doctrine has largely determined the evolution of the European countries, especially relations of church and state remained powerful dynamic within European political long history after the emergence of secular government. ${ }^{2}$ The association of Europe with Christianity can be traced on the evidence from

\footnotetext{
${ }^{1}$ Novalis, "Christendom or Europe" [Die Christenheit oder Europa], 1826.

${ }^{2}$ Mary Anne Perkins, Christendom and European Identity: The Legacy of a Grand Narrative since 1789. Walter de Gruyter, 2004.
} 
several occasions such as between 1492 and 1914, Europeans conquered $84 \%$ of the globe, establishing colonies and spreading theirs influence across every inhabited continent. ${ }^{3}$ Among of the main objectives of theirs colonialism agenda is to spread Christianism, looking for gold and rivalry against Islam, through slogan of Gold, Gospel and Glory. This can be seen on the conquest of Malacca (Malacca is one of flourished state and Islamic center located at South East Asia) by Portugese in $15^{\text {th }}$ centuries. ${ }^{4}$ Another evidence from the conquest of Inca civilization by Spaniards and forced conversion on Catholic religion, which bring to the desctruction of Inca civilization. ${ }^{5}$ The arguments on the Christianity as the identity of Europe is not arguably wrong, as the Pope, religious leader of Catholic Christian resided in europe, the existence of "Holy Roman Emperor" title which started 800 A.D 6 and the clashing power between church and state to dominate influence in European region strengthening the concept of Christendom.

The rising of movement emphasizing Christian identiy as an opposition to the perceived rise of Islam, raise an ontology is Europe still thinking of itself as Christian identity, albeit there has been a gradual movement towards secularization and dechristianization. Since 1968, Europe has been going through major anthropological shifts that have fundamentally separated society's values from Christian values. Making Islam as the central issue, to solidified their stand on Christianity is a bogus one. The

${ }^{3}$ Philip T. Hoffman, "How Europe Conquered the World," Foreign Affairs Magazine, published by the Council on Foreign Relations, October 7, 2015, accessed February 2, 2019. (https://www.foreignaffairs.com/articles/europe/2015-10-07/how-europe-conqueredworld)

${ }^{4}$ Paulo Jorge de Sousa Pinto, Share and Strife - The Strait of Melaka and the Portuguese (16th and 17th centuries). Orientierungen Themenhef (2013), 64-85.

${ }^{5}$ Kaitlynn Harless, "Force and Deceit: The Creation of an Andean-Catholic Religion," Bachelor Honour Thesis, University of Colorado, 2018.

${ }^{6}$ Viscount James Bryce, The Holy Roman Empire, New York: The Macmillan Company, 1911. 
legality of same sex marriage, practice of LGBT (lesbian, gay, bisexsual and transgender), abortion lawful and increasingly demanding of human rights enforcement are all coming from inside Europe itself, voted by people and ratified by their law.

The polemic on the identity of Europe as a christian club still exists until now, although after the reduction of power in term of roles and political power by church and raising of Muslims in Europe. The rising of secularism or paganism among Europeans, separation of religion from individual life does not disappeared the "feeling of Christianity", albeit they do not practice Christian nor believe in God. ${ }^{7}$ The issue can be seen on the reluctant of some European Union countries on the application of Turkey. Some of the them raise an issue if a Muslim country can be considered as part of Europe. ${ }^{8}$ The reluctant approach by some EU countries has triggered a research question, is Europe exclusively only for Christian or Judeo-Christian? Is Europe identity solely belongs to those two semantic religions. How about Islam and its position in Europe? This paper is going to investigate suggestion on the basis that Europe also has roots of Muslim, despite dominant influence of Christianity in historical perspective and contemporary view.

\section{Europe and Christianization process}

Europe itself is often thought of as Eastern and Western Europe, which goes back to the time of Holy Roman Empire (Western) and the Byzantine Empire (Eastern). The Eastern countries consist of Belarus, the Czech Republic, Hungary, Poland, Ukraine, among others on its north

${ }^{7}$ Dale Hurd, "Pagan Europe? Most Europeans Say They Are Christiano Title." The Christian Broadcasting Network, March 3, 2018, accessed February 2, 2019. (https://www1. cbn.com/cbnnews/world/2018/may/pagan-europe-most-europeans-say-they-are-christian)

8 Stephen Kinzer, "Turkey, Rejected, Will Freeze Ties to European Union", The New York Times, December 15, 1997, accessed on February 3, 2019. (https://www.nytimes. com/1997/12/15/world/turkey-rejected-will-freeze-ties-to-european-union.html) 
side and the Balkans-such as Greece, Albania, Bulgaria, Montenegro, Serbia, Romania, Hungary as well as Turkey to its south. The Western countries include Spain, Italy, France, Germany, Austria, England, Sweden, Norway, and Denmark. While Russia is considered Eurasian continent. The venture of Christianism in Europe can be categorized as bloody event in history. ${ }^{9}$ The origins of Christian in Roman Empire is an unknown, while some scholars admitted Christianity found its way into Rome through Jewish community which existed there in first century. ${ }^{10}$ Its became widespread in the Roman Empire, but its' followers constantly violated and persecuted by Empire on their refusal to offer sacrifices to Roman gods and to worship pagan gods. They also became a scapegoats on various of reason such as plagues, economic problems to hostile invasion by barbarians. Christian became illegal religion during that period and first persecution was carried in action under the Emperor of Nero in 64 AD after the Great Fire of Rome. Furthermore, in 303, Christian's followers were undergone severe persecution, called Diocletianic or Great Persecution. During that period several emperors such as Diocletian, Maximian, Galerius and Constantius issued a series of edicts to abolishing Christian's legal rights and forced them to compel with traditional religion practice, paganism. ${ }^{11}$ It is estimated that during Constantius's period Christian's only made up 10\% of Roman's population. ${ }^{12}$ Although, evidence statistic is inadequate, one of the historian of the persecution estimates overall numbers between 5500 and

\footnotetext{
${ }^{9}$ Philip Schaff, History of the Christian Church, Modern Christianity. The German Reformation, Grand Rapids, MI: Christian CLassics Ethereal Library, 2nd ed., Vol. VII, 1882.

${ }^{10}$ James Henry Hingston, "The Origin of Christianity in Rome", The Irish Church Quarterly, Vol. 8, No. 31 (1915), 200-214.

${ }^{11}$ Michael Gaddis, There Is No Crime for Those Who Have Christ : Religious Violence in the Christian Roman Empire, 1st ed. University of California Press, 2005.

${ }^{12}$ Tyler Yung Laughlin, “The Controversy of Constantine's Conversion to Christianity”, Senior Seminar, Western Oregon University, 2007.
} 
6500 people have perished..$^{13}$

It is estimated that about 300 years Christian's followers have been perished under the persecution before Christian was legalized through political agreement in Milan between Roman Emperor (Western) Constantine the Great and Roman Emperor (Eastern) Licinus in February 313.14 The proclaimation of Edict of Milan is regarded as the main ingredients for solidification of Christianity within Roman Empire, the latter transition of Roman Empire to Christian with Constantine became First Christian's Emperor and patron to the church. The proclaimation assured freedom of religions within empire and at the same time reclaimed Christian's legal rights. The ascension of Christianism marked the downfall of paganism, followed by retribution of church towards paganism such as pillaging pagan temples, forbade pagan sacrifice and pagan's followers were attacked by ordinary Christian's followers.

The first anti-pagan law was enacted by Constantius II from 337-361 by prescribed death penalty for those performed or attended pagan sacrifies, worshipping idols, closing of temples and removal of Altar of Victory ${ }^{15}$. Despite of that, anti-pagan policies were quietly resisted by governors and officers due to big numbers of remaining of pagan's followers in Roman's entire population. Subsequently, during Theodosius's era, who became emperor for both empire (Western and Eastern) after defeating Eugenius and Arbogastes in battle of Frigidus, an essence battle for the survival of paganism ${ }^{16}$ saw a zero-toleration towards paganism by executing Magistrates

\footnotetext{
${ }^{13}$ Yuval Noah Hariri, "Sapiens: A Brief History of Humankind”, Harvil Secker, 2015.

${ }^{14}$ Milton Vasil Anastos, "The Edict of Milan (313) : A Defence of Its Traditional Authorship and Designation”, Revue Des Études Byzantines, Vol.25, No. 1 (1967), 13-41.

${ }^{15}$ James Sheridan, "The Altar of Victory - Paganism's Last Battle”, L'antiquité Classique, Vol. 35, No. 1 (1966), 186-206.

${ }^{16}$ Thomas Samuel Burns, Barbarians within the Gates of Rome: A Study of Roman Military Policy and the Barbarians, ca. 375-425 A.D. Birmington and Indianapolis: Indiana University Press, 1994.
} 
who did not enforce anti-pagan law. He also issued Theodosian decrees, a controversy edict which contradict with Edict of Milan, which practically ban practice of Paganism within the empire. ${ }^{17}$ The proclaimation of Edict of Thessalonica in $380 \mathrm{AD}$ made the Nicene Christianity as the state religion, ${ }^{18}$ also signify the beginning of Chritsendom. The anti-paganism continuing carried out after the death of Theodusius, and Christinization of the Roman Empire became complete when Anastasius I Dicorus ascended to emperor and was forced to sign written form of declaration of orthodoxy. ${ }^{19}$ The completion of Christinization in Roman Empire developed Christendom in European continents, any conflicts between Europe civilization and others civilization always basis on the conflict of religion especially with Islam. The integration of Christianism not only taking place within individual life but also taking stage in political and international arena, with Roman Empire seen as the protector of Christian' realm and also center for Christianism's foothold.

\section{Europe and early Islamic presence}

After 200 years on the completion of Christinization in Roman Empire, Islam came to Europe through several occasion by Arab during Umar and Umayyad period. In $652 \mathrm{AD}$, after established first navy, Arab launched a small invasion against Byzantine Siciliy but not succeed until full conquest began on 827-902. ${ }^{20}$ Islam gained first stronghold through Umayyad conquest on Hispania (Spain and Portugal), renamed as Al-Andalus in 711. As opposed the Christinization process within Roman Empire, the

${ }^{17}$ Clyde Pharr, "Review: The Theodosian Code", The Jewish Quarterly Review, Vol. 43, No. 4 (1953), 392-394.

18 Eugenia Russell, Literature and Culture in Late Byzantine Thessalonica, London: Bloomsbury, 2013.

${ }^{19}$ Georgije Ostrogorski, History of the Byzantine State. Revised. New Jersey: Rutgers University Press, 1969.

${ }^{20}$ Leonard C. Chiarelli, A History of Muslim Sicily. Midsea Books, 2011. 
conquest of Muslim is welcomed by Spanish Jewish Community as liberator from the oppression of the Catholics. ${ }^{21}$ In stark contrast, Islam presence within Europe always seen as a threat to the the existence of Christianism and saw as militarily seized territory from native Iberian Christian, which in latter years Christian's kingdoms called for reconquista againts Muslim's presence. The Islamic civilization in Spain encompasses many field that left a profound imprint in the Iberian Peninsula and Europe. During that period literature and art were flourished, many buildings were constructed based on Islamic arts. At the same time, Cordoba became the civilization capital for both Spain and west in general. As capital of civilization, Cordoba was known as for its scientific advance, which played vital role in the revolution of science. This was not limited to Cordoba alone, but was spreaded to other cities under Islamic rule, for instance Granada, Toledo and etc. According to historical sources, Pope Sylvester II (other name Gerbert) hase been enrolled at some universities in Andalusia and introduce science of mathematics and Arabic numerals in Italy. ${ }^{22}$

Furthermore, contribution of Islam towards European Civilization can be seen when muslim scholar's manusripts such as Ibn Sina, Al Farabi, Ibn Tufayl, Ibn Bajjah and Ibn Rushd quickly spreads all over Europe and became mandatory literature in European universities. This period, oftenly called as "Golden Age" for Islamic civilization, while progress of scientific knowledge in Europe languished in Dark Age. The Arabic language became the chief vehicle for the spread of knowledge, generally in scientific fields. Largely, this contribution can be evidence during Medieval Age such as history writing by Muslim historians which were characterized by accuracy, scientific assembling of facts and their objective approach ${ }^{23}$ and advancement

\footnotetext{
${ }^{21}$ David Nicolle, The Great Islamic Conquests AD 632-750, Oxford: Osprey, 2009.

${ }^{22}$ Safvet Halilovi', "Islamic Civilization in Spain - A Magnificient Example of Interaction and Unity of Religion and Science", Psychiatria Danubina, Vol. 29, Suppl. 1, (2017): 64-72.

${ }^{23}$ Samee Ullah Bhat, "Muslim Contribution To History Writing During The Medieval
} 
of Islamic medicine by Al-Razi who wrote about Kitab Al-Hawi Fi Al-Thib (The Comprehensive Book on Medicine), a 23 volume of textbook that became main medical curriculum for European schools in $14^{\text {th }}$ century, Ibn Sina, who wrote Al-Qanun Fi Al-Thibb (The Canon Medicine) and Mansur, who firstly wrote color illustrated book on Anatomy. ${ }^{24}$ These books and ideas provided was the basis for medical care in Europe during its recovery from Dark Age. In mathematical field, Al-Khwarizmi developed modern Al-Gebra, while in physic field, Abual Rihan Al Beruni, who defined the ratio between densities of gold, mercury, lead, silver, bronze, copper, brass, iron and tin. ${ }^{25}$ Subsequently, thanks to the Muslim scientific advancement which contributed towards the Renaissance era. ${ }^{26}$ The significant of Muslim presence in Europe undeniably importance as Muslim plays vital role in shaping what today Europe is. By promoting multi-racial integration or convivencia among Muslim, Christian and Jews, the three monotheistic religions sit together with peace and harmony under Muslim rule. This mutual co-existence period was created by social cooperation, religious tolerance and cultural impact. This is indeed an important landmark that shows Islamic presence not solely for conquest but also reshaping the society through knowledge advancement and sharing. The reasons for this argument is, it is impossible to create "knowledge creation" if the society in disorder and distress situation. The allocation of resources and the social development will become stagnant, but, Andalus not only became center of Islamic civilization but also a center of knowledge in Europe.

Times: (An Overview)", Asian Journal Of Multidisciplinary Studies, Vol. 4, No. 2 (2016): 126-30.

${ }^{24}$ Hawa Edriss, Brittany N. Rosales, Connie Nugent, Christian Conrad, and Kenneth Nugent. "Islamic Medicine in the Middle Ages", The American Journal of the Medical Sciences, Vol. 354, No. 3 (2017), 223-29.

${ }^{25}$ Muhammad Adil Afridi, "Contribution of Muslim Scientists to the World: An Overview of Some Selected Fields", Revelation and Science, Vol. 03, No. 1 (2013), 47-56.

${ }^{26}$ George Sarton, Introduction to the History of Science, New York: Carnegie Institution of Washington, Baltimore, 1927. 


\section{Declination of Andalusia in Europe and rising of Ottoman empire}

Muslim power in Hispania prevailed almost 800 years (711-1492) before continued to wane until the last Muslim dynasty was defeated in Granada in 1492 by Catholic royal powerhouse Queen Isabel of Castile and King Ferdinand of Aragon conquered Granada, which brings end Muslim rule in Spain to the end. The conquest of Spain brings to the expulsion of Muslims and Jews, despite the promise made by the Boabdil (late sultan) on the surrender of Granada, Treaty of Granada 1491, which allowed Muslims and Jews to practise their faith. The treaty was violated, mosques were being converted to Cathedral, Archbishop Cisneros ordered the mass conversions of Muslims and Jews into Christian. To add more, he also ordered the burning ten thousands of Arabic manuscripts on valuable knowledge. By 1502, the monarchs had made Islamic practice as illegal in Spain. ${ }^{27}$ With that, it can be concluded that the spirit of Christianism is always a main agenda by European medieval countries as a main slogan to driven out any of theirs enemy whether enemy of invasion or enemy during colonialism. The European at that time proudly saw themselves as an "enlightenment people" and any religions that is outside of Christianity is considered as heretical. In addition, the close relationship between royal house and church, solidified the creation of Christian's sphere in Europe. The support given by church regarded as backbone power for royal house to stay in power. It is also one of the main elements to call people rally on their side in needed time.

The fall of Granada is not the end of Muslim presence in Europe as its predecessor Ottoman Empire continued Muslim expansion in Europe, which latter shaped the history of South Eastern Europe. The foundation

${ }^{27}$ Sabera Ahsan, "This Is What Happened to Muslims and Jews after the Fall of Islamic Spain in 1492”, Muslim.com, April 17, 2017, accessed on February 7, 2019 (https://mvslim. $\mathrm{com} /$ this-is-what-happened-to-muslims-and-jews-after-the-fall-of-islamic-spain-in-1492/) 
of Ottoman Empire started in 1281 by Ottoman I and his victory over Byzantine at Bapheon. His legacy was succeeded by Orhan Bey through his conquest on Bursa which marked the beginning of Ottoman expansion into the Balkan, South Eastern Europe. ${ }^{28}$ Allied himself with Byzantine Emperor through political marriage with Theodora, daughter of John VI Cantacuzenus, gave him an access of knowledge on Balkan's area which he managed to conquered Gallipoli as a permanent foothold in Europe. The conquest of South Eastern Europe was continued by Ottoman rulers and actually became one of theirs foreign policy expansion towards Europe. This can be seen Murad I conquest Thrace, Edirne, Macedonia and parts of Greece and Albania. Bayezid I annexed Bulgaria, Mehmet I conquest of Dobruja, Giurgiu and Turnu. ${ }^{29}$ In due course of Ottoman's peak power in term of militarily and politically, they finally conquered the capital of Byzantine Empire, Constantinople (presently, Istanbul) in 1453 under Mehmet Al-Fateh. Subsequently, Ottoman Empire replaced Eastern Roman Empire (Byzantine Empire) as the major power in the Eastern Mediterranean. The fall of Constantinople sent a shockwaves throughout Christendom due to the importance position plays by the city's as the bastion of Christian Europe against advancement of Muslim Asia. The fall of the city's also signify the gained of Muslim's foothold in Europe permanently unchallengeable till present. In addition, its saw the mass conversion of Christian to Islam in Balkan area vountarily, while non-Muslims able to profess their religion freely and given an autonomy to administer their affairs through "millet" system. ${ }^{30}$ As part of social

${ }^{28}$ Yahya Başkan, "Orhan Bey'in Bizans İmparatoru Kantakuzeneos'un Kizi Theodora İle Evliliği”, Tarih Dergisi, Vol. 2, No. 66 (2017), 47-61.

29 Bogdan Murgescu and Halil Berktay, The Ottoman Empire, Edited by Christina Koulouri, ( $2^{\text {nd }}$ ed.), Athen: Center of Democrary and Reconciliation in Southeast Europe, 2005.

${ }^{30}$ James R. Payton Jr, "Ottoman Millet, Religious Nationalism, and Civil Society: Focus on Kosovo", Occasional Papers on Religion in Eastern Europe, Vol. 26, No. 1 (2006), 11-23. 
tolerance policy, Muslims and Christians co-exist peacefully within the Empire, this can be saw by many churches and the present population in Balkan still dominated by Orthodox Christian.

\section{Ottoman empire reshaping Europe}

Ottoman Empire dominated South Eastern Europe for almost 500 years before the greatest Muslim empire of all time collapsed after World War 1 in (1908-1922). Due to its size, and length of its domination the Ottoman Empire has a tremendous historical importance in shaping western civilization. As compare to Andalus and Granada previously, the Ottoman Empire is considered as biggest political power in Europe due to its territory occupied most of part that had been under old Roman Empire. In addition, the Empire managed to inscribed strongly their identification as part of Europe, ${ }^{31}$ theirs legacy of millet system presently still in practise, and its predecessor, Turkey indirectly holds soft sphere of power towards ex-Ottoman's splitted countries in Balkan area. ${ }^{32}$

Ottoman's contribution can be evidence from their expertise in arts and crafts. ${ }^{33}$ At their height of power, they are leader in cartography and also influenced western musicians such as Mozart and Beethoven. One of biggest contribution of Ottoman in shaping Europe, perhaps can be considered as developing social integration of multi-religions within Europe. This is because thoroughout the history, Christendom tend to perceive other religion as heretical and Vatican altogether with State's

\footnotetext{
${ }^{31}$ Daniel Goffman, The Ottoman Empire and Early Modern Europe, Cambridge: Cambridge University Press, 2002.

${ }^{32}$ Michael Birnbaum, "Turkey Brings a Gentle Version of the Ottoman Empire Back to the Balkans", The Guardian, April 2, 2013, accessed on February 5, 2019 (https://www. theguardian.com/world/2013/apr/02/bosnia-turkey-ottoman-influence-balkans-sarajevo).

33 Carma Wadley, "Ottomans Had a Big Impact on Western Civilization", Deseret News, August 15, 2002, accessed on February 20, 2019 (https://www.deseretnews.com/ article/931174/Ottomans-had-a-big-impact-on-Western-civilization.html).
} 
under its dominant tend to violate any signed peace-treaty and practise mass expulsion and conversion to Christian. The legal tolerance during Ottoman Empire can be viewed in present day through the existence of Muslims, Christians and Jews communities in Balkan area. In compare to Catholic "reconquista" (reclaimation) of Iberian Peninsula which caused expulsion and forced conversion toward Christianity, including burning of valuable knowledge, Ottoman Empire do not seek forced conversion due to financial interest in non-muslims, who obliged to pay extra taxed. ${ }^{34}$ This situation indeed bring stability in the region itself and allowed the preservation of multicultural and self-identity of ethnicities through millet system practice.

In addition, by replacing the Byzantine Empire, indirectly Ottoman Empire reshaping the geograpy of Europe itself, bringing Islamic rule and Islamic identity with them. For the past centuries, Christendom beliefs Europe is a sacred land only for them, which create egoism and supremacy of western countries especially Christian kingoms against Asian civilization, specifically the Muslim. The hope of Vatican to extinguish the light of Islam within Christendom did not end well, thanks to Ottoman Empire several countries in Balkan area, as an example of these countries have big number of Muslims population; Albania, Kosovo and Bosnia \& Herzegovina. And Muslims also widely spreaded in another Balkan regions such as in Greek, Serbia, Montenegro and Croatia. The establishment of Islam in Balkan, genuinely called by scholars as Balkan Islam or European Islam. ${ }^{35}$

${ }^{34}$ Svetoslav Ribolov, "The Orthodox Church in the Ottoman Empire and Its Perspectives for Theological Dialogue”, Occasional Papers on Religion in Eastern Europe, Vol. 33, Issue 2 (2013), 7-24.

${ }^{35}$ Xavier Bougarel,"Balkan Muslim Diasporas and the Idea of a "European Islam”, Uppsala Multiethnic Papers, Vol. 49, (2005), 147-65. 


\section{Contemporary identification of Europe}

The event of Catholic' declination of power saw the separation of state and individual life from religious control. There are several occasions that lead to such declination event such as power struggle between Pope Gregory VI and Henry IV and age of Renaissance which accelerated the process, when people start to think out of the box in seeking for truth. In the $16^{\text {th }}$ century, Martin Luther who became fed up with the church practise of selling indulgences and he began the Protestan Reformation which divide Europe geographically between Protestan North and Catholic south. ${ }^{36}$ The advancement of scientific revolution such as emergent of philosophy by Aristotle, Galileo Galilei's theory of solar system and Copernican's theory of the universe has shaken the foundation of beliefs that has been preached by the church. ${ }^{37}$ Through of these occasional events, the unity of the European continent in terms of religion had been broken. The introduction of secularism and national identity are getting the way in shaping identity of Europe. Since the signing of the Treaty of Rome 1957 that established the European Economic Community (EEC) and initated the ongoing process of European Integration, western European societies have undergone a rapid, drastic and seemingly irreversible process of secularization. The limitation power of religious bodies, some countries constitution invoke Christianity, religious diverse society and raising numbers of self-declared atheism and agnostics have diminished shared identity of Christianity. ${ }^{38}$

\footnotetext{
${ }^{36}$ Jerry Pillay, "Reformation and Transformation Today: Essentials of Reformation Tradition and Theology as Seen from the Perspectives of the South", HTS Teologiese Studies/ Theological Studies, Vol. 73, No. 3, (2017), 1-6.

${ }^{37}$ Nicholas P. Leveillee, "Copernicus, Galileo, and the Church: Science in a Religious World”, Inquiries Journal, Vol. 3. No. 5, (2011), 1-2.

${ }^{38}$ Ronan McCrea, "How to Hobble Religion Contrary to Popular Belief, Migration from Muslim Countries Is One Reason Why Europe Is Becoming More Secular, Not Less." Aeon, June 17, 2013, accessed on February 10, 2019 (https://aeon.co/essays/is-migration-making-
} 
The contemporary identification of Europe undeniably an interested topic for discussed. The declination of Pope's power, emergence of secularism and nationalism, and also the raising of Islam shaping the latest identification of Europe. Presently, Islam is the fastest growing religion in the sacred land of Christendom due to large migration of Muslims, with solid statistic evidence that it might be triple by $2050 .{ }^{39}$

Table 1: Effect of Migration on European Population ${ }^{40}$

\begin{tabular}{lccccc}
\hline & 2010 & 2016 & 2050 & 2050 & 2050 \\
\hline & & & $\begin{array}{c}\text { Zero- } \\
\text { migration }\end{array}$ & $\begin{array}{c}\text { Medium } \\
\text { migration }\end{array}$ & $\begin{array}{c}\text { High } \\
\text { migration }\end{array}$ \\
Muslims & $19,5 \mathrm{mil}$ & $25,8 \mathrm{mil}$ & $35,8 \mathrm{mil}$ & $57,9 \mathrm{mil}$ & $75,6 \mathrm{mil}$ \\
Non-Muslims & $495,3 \mathrm{mil}$ & $495,1 \mathrm{mil}$ & $445.9 \mathrm{mil}$ & $459,1 \mathrm{mil}$ & $463.0 \mathrm{mil}$ \\
Total & $514,8 \mathrm{mil}$ & $520,830,000$ & $481,7 \mathrm{mil}$ & $516,9 \mathrm{mil}$ & $538,6 \mathrm{mil}$ \\
\hline
\end{tabular}

The rising of Muslim in Europe has made Islam as the second largest religion after Christianity. The term of "Muslim Europe" no longer can be erased nor modified as its covered Muslim presence in European countries, largely in Balkan area. Although, some countries fear on the rising of Muslim, they have integrated into European society in the last decades, contributed to its economy, its culture, and have developed a peaceful-attitude of Islam that enables them to integrate into Western culture. ${ }^{41}$ Furthemore, the reluctant of some European

europe-more-secular).

${ }^{39}$ Harriet Sherwood, "Muslim Population in Some EU Countries Could Triple, Says Report”, The Guardian, November 29, 2017, accessed on February 10, 2019 (https://www. theguardian.com/world/2017/nov/29/muslim-population-in-europe-could-more-thandouble)

${ }^{40}$ Conrad Hackett, Phillip Connor, Marcin Stonawski, and Michaela Potancokova, "Europe's Growing Muslim Population: Muslims Are Projected to Increase as a Share of Europe's Population - Even With...” Pew Research Center, 2017.

${ }^{41}$ David Stavrou, “No, Europe Isn't Returning to the Bosom of Islam”, Haaretz, October 
countries to recognize history truth on the "Christian roots of Europe" in its new constitution sparked the dubious identification. This is because mentioning Christianity and God was considered too controversial and will spark furious opposition from secularism and Protestan countries, and also considered wrong to exclude Muslims and Jews regarding on the religious reference. ${ }^{42}$

Based on the historical perspective, it is concluded that Europe is a Christendom domain due to anti-pluralism and majority of countries adhere to Christianity. The expulsion of Muslims in Granada and jointcrusade against Muslims in Sicily and Ottoman Empire shows the alliance of late European countries against presence of Muslims in Europe. In addition, the transition power from state to church during Medieval Age shows how Christianity permeated in all stages of European' people's life, ranging from individual values, laws, cultures, politics and knowledges. The fall of Iberian peninsula and Sicily to Muslims, should be marked as the beginning of new identity of Europe, as a multiculturalism continent. However, this multiculturalism idea and social tolerance among Abrahamic religions was not so welcoming among late European kingdoms. The fall of Constantinople, marked a new chapter, change drastically the political landscape and geography of Europe. The South Eastern Europe or Balkan became known as European Muslim. In addition, its became the permanent door for Islam spreaded more widely into Western Europe, with the practice of Ottoman "millet system" they promoting social tolerance and multiculturalisn of religions which is invalidly to be practice under Christianity rule. Religious pluralism

18, 2018, accessed on February 11, 2019 (https://www.haaretz.com/world-news/europe/noeurope-isn-t-returning-to-the-bosom-of-islam-1.6572926)

42 Ian Black, "Christianity Bedevils Talks on EU Treaty." The Guardian, May 25, 2004, accessed on February 11, 2019 (https://www.theguardian.com/world/2004/may/25/ eu.religion) 
practise by Ottoman bringing three Abrahamic religions co-existing peacefully which in latter years plays pivotal role in shaping the current identification of Europe.

The increasing of Muslims presence in European countries making the continent hardly longer to be recognized as a single identity based on the Christianity. As wroted by famously Anglo-French writer and historian, Hillaire Beloc, "Europe will return to the Faith, or she will perished. The Faith is Europe, and the Europe is the Faith". ${ }^{43}$ The quote strongly signify the unbroken relationship between Christianity and Europe. However, the current situation shows otherwise where the Christianity is losing grips on the modern society of European. The issue of gay marriages, raising of atheism, abortion and separation of Protestan and Catholician make it harder to solidify the position of Christianity within the society. Moreover, the sharply increasing secularism make Christianity as default is gone and showing majority of young people becoming non-Christian. For instances $70 \%$ of young people in United Kingdom identify with no religion, with largest recorded in Czech Republic 91\% and average score around 50\% in other Europe countries. ${ }^{44}$

Furthermore, as mentioned before this paper agreed on the Europe being a Christendom in the past time due to their intolerable action against religion pluralism within their domain, but to denied any root of Islamic presence within the domain during that time and its role in forming Europe is totally unacceptable. This is because during Golden Age of Cordova, Muslim civilization surpassed entire Europe civilization

\footnotetext{
${ }^{43}$ Rusell Shaw, "Secularists Erase Christianity from European History." The Catholic World Report, August 3, 2017, accessed on February 13, 2019 (https://www.catholicworldreport. com/2017/08/03/secularists-erase-christianity-from-european-history/).

${ }^{44}$ Harriet Sherwood, "Christianity as Default Is Gone': The Rise of a Non-Christian Europe." The Guardian, March 21, 2018, accessed on February 13, 2019 (https://www. theguardian.com/world/2018/mar/21/christianity-non-christian-europe-young-peoplesurvey-religio).
} 
and its scientific advancement and manuscripts became European's reference. Through these knowledges, European managed to reached Age of Renaissance and in latter years developed their own civilization and becoming center of the world. However, the contribution given by Muslim scholar and Islamic civilization's achievement to the world and European Renaissance have not received due recognition. ${ }^{45}$ It is something to be pondering, why this huge contribution by Muslims never got any attention and it seem to be buried by the time. The lack of this recognition and Islamic roles in European claimed to be due of religious animosity towards Islam and a sense of inferiority in Europe have been partly responsible for European reticence in acknowledging their debt to earlier Muslim works. ${ }^{46}$ It seems that by acknowledging Muslim contribution, subsequently will jeopardise dominance of western cultural and its hemegony. Furthermore, it is a crucial measure to be taken to protect fundamental concept that Europe was founded based on JudeoChristian values and hardship gone through by early Christian followers who were martyrdom during early period of Christianism. Because of that, the boundaries was set up between Islam culture and Christian culture. These arguments was supported by some of scholars ${ }^{47}$ who claimed that Europe fears that real multiculturalism environment might transform what Europe today, which is include Islam. Also, Europe perceive Islam as a transcruptive force that, through transculturation processes, might be able to challenge the alleged Judaeo-Christian heritage of Europe. ${ }^{48}$

\footnotetext{
${ }^{45}$ Ahmed Essa and Othman Ali, Studies In Islamic Civilization The Muslim Contribution to the Renaissance, Edited by Anas S. Al-Shaikh-Ali and Shiraz Khan. 1st ed. London: The International Institute of Islamic Thought, 2012.

${ }^{46}$ Nayef R.F Al-Rodhan, The Role of the Arab-Islamic World in the Rise of the West: Implications for Contemporary Trans-Cultural Relations,Basingstoke: Palgrave Macmillan, 2012.

${ }^{47}$ Gabriele Marranci, "Multiculturalism, Islam and the Clash of Civilisations Theory: Rethinking Islamophobia”, Culture and Religion, Vol. 5, No.1 (2004), 105-117.

${ }^{48}$ Barnor Hesse, Introduction: Un/Settled Multiculturalism. London: Zed Books, 2000.
} 
Presently, to suggest European continent as Christendom is contestable due to diversity of religions, gradual movement towards secularization and dechristianization. Albeit, majority of Europe identify themselves as Christian, many of them living their lives without adhering to Christian values, which accelerating the process of dechristianization. ${ }^{49}$ In fact, by claiming European as Christian identity after the fall of Byzantine Empire is questionable unless specifically focus on Western part only. This is because after the fall of Byzantine Empire, and its territories being conquered by Ottomans saw that area under Islamic rules. The Ottomans has brought along them the new administrative order, primarily based on Islamic Sharia law..$^{50}$ The implementation of Sharia law in Balkan area and the presence of Muslim rules diminished the sphere of Christendom in South Eastern Europe. Therefore, calling Europe (Eastern and Western) as Christendom is contentious.

It is undebatable that Europe is rooted from Christianity, but saying Islam ingrained in European should also not being indisputable. The history of Europe is complex, but based on chronology early Europe is Paganism, Judeo-Christian, Christianity and Islam, accordingly. Henceforth, denying the term of Muslim Europe is totally disagreeable. The debate of European lossing identity in fearing of Islam is considered wildly unreasonable, because Islam already there since an establishment of Andalus and existence of Muslims in Sicily. Whether by conquest or not, it is should not be a matter of today, as many continents and several countries unwillingly accepted they have been colonized and converted during colonialism period without denying the truth about it. It is like

${ }^{49}$ Isabelle de Gaulmyn and Jean-Christophe Ploquin, "Is Europe Still Christian." La Croix International, January 14, 2019, accessed on February 13, 2019 (https://international. la-croix.com/news/is-europe-still-christian/9224\#)

${ }^{50}$ Ema Miljkovic, "Ottoman Heritage in the Balkans: The Ottoman Empire in Serbia”, Süleyman Demirel Üniversitesi Fen-Edebiyat Fakültesi Sosyal Bilimler Dergisi, Vol. 2, No. 2009, (2014), 129-137. 
denying the reality or historical events that already taken place and manipulating history, just to hold up supremacy thinking of Christian civilization against Muslim civilization.

Besides, referring to the contemporary situation in Europe, it is no longer should be identified with Christianity or "Christian club" term. The rising of secularism, atheism and hedonism have lessening the spirit of Christianity and its value within individual, altogether the society. It is a matter of time whether people ready to accept the current reality or to stay in blindfoldedly. According to the think tank organization Pew Research Center, Christianity has shifted from Europe to Africa. ${ }^{51}$ With that, it is believed that Europe is no longer center gravity for Christianity. The rising of Muslims which already integrated culturally and socially should also not been undermined as they are already been part of European community.

\section{Conclusion}

The myth of a "Christian Europe" based on the identification of the European continent solely with Christianity should be modified and altered. This is a malicious and mythical claim that has been calamitously employed throughout history in most episodes of ethnic cleansing agains non-Christians in Europe, from the purging of Pagans and expulsion of Muslims and Jews from Spain in 1492. An entirely Christian Europe has been aspiration of some political and religious ideologues for centuries but genuinely it was a historical aberation. This is because Europe was religiously diverse, with vibrant Jewish and Muslim communities. To deny any presence of them, especially Muslim position is like putting Europe annals of history in void. The factual proof, if still needed, of

${ }^{51}$ David Masci, "Christianity Poised to Continue Its Shift from Europe to Africa", Pew Research Center, April 7, 2015, acessed on February 12, 2019 (https://www.pewresearch.org/ fact-tank/2015/04/07/christianity-is-poised-to-continue-its-southward-march/) 
Europe Muslim history and heritage because one cannot mass murder a people who do not exist.

Furthermore, it seemed that Muslim existed in Europe for a while and contributed to the European civilization. Although one migt forgive what happened in the end, one must not forget that Muslim once flourished from Spain and Sicily, and later became mighty political power in area of South Eastern Europe (Balkan) region during reign of Ottoman Empire. And that factually Europe was not only Christian but also Muslim in the past, as it is today. Past in the making, or revision need to be done. Discarding Islam legacy and its foundation is one of the worst history legacies in humankind. The concept of "winner" rewrite history should no longer be taking place in academic world nor in history book. As our civilization moving forward, the truth will uncover sooner or later. The denial and arrogance of Western academicians and politicians in recognizing Muslim roles in shaping Europe, subsequently implying that Muslim have no place in Europe because they are "foreigners" is groundless. In addition, rejection of Turkey to be part of Europe on basis of Muslim country also totally baseless. Ironically, in term of ontological and epistemological, the evidence of Muslim in Europe are very clear and solid, the very reasons why until now Muslim position is still not being acknowledge is really amusing and confusing. Is the supremacy of Westerner against Asian, notably Muslim should be prolong? The question of supremacy thinking on the belief that Westerners are somehow superior to people of other racial backgrounds, and should therefore politically, economically, and socially rule over non-white should be uphold? This way of thinking is a disease that if not quarantined or contained will keep erupting in extreme ways and will destroy humanity values.

In conclusion, this paper suggested that Islam do have its presence in Europe since the establishment of Umayyad dynasty in Andalus 
and Sicily. The presence of Islam in Europe was later strengthened by Ottomans in Balkan area as an imperial superpower for six centuries. The installation of Muslim in Iberian Peninsula and Sicily, promotion of social cultural interaction called convivencia promoting interfaith life in Europe ${ }^{52}$. The cross cultural existence in Europe was not only succeeded after the occupancy of South Eastern Europe by Ottomans, but also shaping the geography of Europe until present. Perhaps, it is acceptable to justified that Europe (Eastern and Western) already dwindled into multiculturalism instead of Christian's sole domain after the inception of Muslims in Iberian Peninsula.

\section{Bibliography}

Afridi, Muhammad Adil, "Contribution of Muslim Scientists to the World: An Overview of Some Selected Fields", Revelation and Science. Vol. 03, No. 1 (2013): 47-56.

Ahsan, Sabera, "This Is What Happened to Muslims and Jews after the Fall of Islamic Spain in 1492”, Muslim.com, April 17, 2017, accessed on February 7, 2019 (https://mvslim.com/this-is-what-happened-tomuslims-and-jews-after-the-fall-of-islamic-spain-in-1492/)

Akasoy, Anna, "Review Article: Convivencia And Its Discontents: Interfaith Life In Al-Andalus", International Journal of Middle East Studies, Vol. 42, No. 3 (2010): 489-499.

Al-Rodhan, Nayef R.F. The Role of the Arab-Islamic World in the Rise of the West: Implications for Contemporary Trans-Cultural Relations. Basingstoke: Palgrave Macmillan, 2012.

Anastos, Milton V, "The Edict of Milan (313) : A Defence of Its Traditional Authorship and Designation”, Revue Des Études Byzantines, Vol.25, No. 1 (1967): 13-41.

Başkan, Yahya. Başkan, Yahya, “Orhan Bey’in Bizans İmparatoru

${ }^{52}$ Anna Akasoy, "Review Article: Convivencia And Its Discontents: Interfaith Life In AlAndalus." International Journal of Middle East Studies. Cambridge University Press. Vol. 42, No. 3, (2010), 489-499. 
Kantakuzeneos'un Kizi Theodora İle Evliliği." (The Marriage of Orhan with Theodora, daughter of Kantakuzeneo, Emperor of Byzantine), Tarih Dergisi, Vol. 2, No. 66 (2017): 47-61.

Bhat, Samee Ullah. "Muslim Contribution To History Writing During The Medieval Times: (An Overview)", Asian Journal Of Multidisciplinary Studies 4, no. 2 (2016): 126-30.

Birnbaum, Michael, "Turkey Brings a Gentle Version of the Ottoman Empire Back to the Balkans", The Guardian, April 2, 2013, accessed on February 5, 2019. (https://www.theguardian.com/world/2013/ apr/02/bosnia-turkey-ottoman-influence-balkans-sarajevo).

Black, Ian, "Christianity Bedevils Talks on EU Treaty", The Guardian, May 25, 2004, accessed on February 11, 2019 (https://www.theguardian. $\mathrm{com} /$ world/2004/may/25/eu.religion)

Murgescu, Bogdan and Halil Berktay. The Ottoman Empire. Edited by Christina Koulouri, (2nd ed.). Athen: Center of Democrary and Reconciliation in Southeast Europe, 2005.

Bougarel, Xavier, "Balkan Muslim Diasporas and the Idea of a "European Islam”, Uppsala Multiethnic Papers 49 (2005): 147-65.

Burns, Thomas S. Barbarians within the Gates of Rome: A Study of Roman Military Policy and the Barbarians, ca. 375-425 A.D. Indiana University Press, 1994.

Chiarelli, Leonard C. A History of Muslim Sicily. Midsea Books, 2011.

Edriss, Hawa, Brittany N. Rosales, Connie Nugent, Christian Conrad, and Kenneth Nugent. "Islamic Medicine in the Middle Ages", The American Journal of the Medical Sciences, Vol. 354, No. 3 (2017): 223 29.

Essa, Ahmed, and Othman Ali. Studies In Islamic Civilization The Muslim Contribution to the Renaissance. Anas S. Al-Shaikh-Ali and Shiraz Khan (ed.). 1st ed. London: The International Institute of Islamic Thought, 2012.

Gaddis, Michael. There Is No Crime for Those Who Have Christ : Religious

Violence in the Christian Roman Empire. 1st ed. University of California Press, 2005.

Gaulmyn, Isabelle de, and Jean-Christophe Ploquin, "Is Europe Still 
Christian", La Croix International, January 14, 2019, accessed on February 13, 2019 (https://international.la-croix.com/news/iseurope-still-christian/9224\#)

Goffman, Daniel. The Ottoman Empire and Early Modern Europe. Cambridge: Cambridge University Press, 2002.

Hackett, Conrad, Phillip Connor, Marcin Stonawski, and Michaela Potancokova, "Europe's Growing Muslim Population: Muslims Are Projected to Increase as a Share of Europe's Population - Even With..." Pew Research Center (2017): 1-58.

Halilović, Safvet, "Islamic Civilization in Spain - a Magnificient Example of Interaction and Unity of Religion and Science", Psychiatria Danubina, Vol. 29, Suppl. 1 (2017): 64-72.

Hariri, Yuval Noah. Sapiens: A Brief History of Humankind. London: Harvil Secker, 2015.

Harless, Kaitlynn, "Force and Deceit: The Creation of an Andean-Catholic Religion," Bachelor Honour Thesis, University of Colorado, 2018. Hesse, Barnor. Introduction: Un/Settled Multiculturalism. London: Zed Books, 2000.

Hingston, James Henry, "The Origin of Christianity in Rome”, The Irish Church Quarterly, Vol. 8, No. 31 (1915): 200-214.

Hoffman, Philip T, "How Europe Conquered the World", Foreign Affairs Magazine, published by the Council on Foreign Relations, October 7, 2015, accessed February 2, 2019. (https://www.foreignaffairs. com/articles/europe/2015-10-07/how-europe-conquered-world)

Hurd, Dale, "Pagan Europe? Most Europeans Say They Are Christiano Title", The Christian Broadcasting Network, March 3, 2018, accessed February 2, 2019 (https://www1.cbn.com/cbnnews/world/2018/ may/pagan-europe-most-europeans-say-they-are-christian)

Kinzer, Stephen, "Turkey, Rejected, Will Freeze Ties to European Union”, The New York Times, December 15, 1997, accessed on February 3, 2019. (https://www.nytimes.com/1997/12/15/world/ turkey-rejected-will-freeze-ties-to-european-union.html)

Laughlin, Tyler Yung, "The Controversy of Constantine's Conversion to Christianity”, Senior Seminar, Western Oregon University, June 15, 
2007.

Leveillee, By Nicholas P., "Copernicus, Galileo, and the Church: Science in a Religious World", Inquiries Journal, Vol.3, No. 5 (2011): 1-2.

Marranci, Gabriele, "Multiculturalism, Islam and the Clash of Civilisations Theory: Rethinking Islamophobia”, Culture and Religion, Vol.5, No. 1 (2004): 105-17.

Masci, David, "Christianity Poised to Continue Its Shift from Europe to Africa", Pew Research Center, April 7, 2015, acessed on February 12, 2019 (https://www.pewresearch.org/fact-tank/2015/04/07/ christianity-is-poised-to-continue-its-southward-march/)

McCrea, Ronan, "How to Hobble Religion Contrary to Popular Belief, Migration from Muslim Countries Is One Reason Why Europe Is Becoming More Secular, Not Less”, Aeon, June 17, 2013, accessed on February 10, 2019 (https://aeon.co/essays/is-migration-makingeurope-more-secular).

Miljkovic, Ema, "Ottoman Heritage in the Balkans: The Ottoman Empire in Serbia, Serbia in the Ottoman Empire", Süleyman Demirel Üniversitesi Fen-Edebiyat Fakültesi Sosyal Bilimler Dergisi, Vol.2, No. 2009 (2014): 129-37

Nicolle, David. The Great Islamic Conquests AD 632-750. Osprey, 2009.

Novalis. "Christendom or Europe" [Die Christenheit Oder Europa], 1826.

Ostrogorski, Georgije. History of the Byzantine State. Revised. New Jersey:

Rutgers University Press, 1969.

Paulo Jorge de Sousa Pinto, "Share and Strife - The Strait of Melaka and the Portuguese (16th and 17th Centuries)", Orientierungen Themenhef (2013): 64-85.

Payton Jr, James R., "Ottoman Millet, Religious Nationalism, and Civil Society: Focus on Kosovo", Occasional Papers on Religion in Eastern Europe 26, no. 1 (2006): 11-23.

Perkins, Mary Anne. Christendom and European Identity: The Legacy of a Grand Narrative since 1789. Walter de Gruyter, 2004.

Pharr, Clyde. Pharr, Clyde, "Review: The Theodosian Code", The Jewish Quarterly Review, Vol. 43, No. 4 (1953): 392-394.

Pillay, Jerry, "Reformation and Transformation Today: Essentials of 
Reformation Tradition and Theology as Seen from the Perspectives of the South," HTS Teologiese Studies/Theological Studies, Vol 73, No. 3 (2017): $1-6$

Ribolov, Svetoslav, "The Orthodox Church in the Ottoman Empire and Its Perspectives for Theological Dialogue”, Occasional Papers on Religion in Eastern Europe. Vol. 33, Issue 2 (2013): 7-24.

Russell, Eugenia. Literature and Culture in Late Byzantine Thessalonica. London: Bloomsbury, 2013.

Sarton, George. Introduction to the History of Science. New York: Carnegie Institution of Washington, Baltimore, 1927.

Schaff, Philip. History of the Christian Church, Modern Christianity. The German Reformation. Grand Rapids. MI: Christian CLassics Ethereal Library, 2nd ed., Vol. VII, 1882.

Shaw, Russell, "Secularists Erase Christianity from European History", The Catholic World Report, August 3, 2017, accessed on February 13, 2019 (https://www.catholicworldreport.com/2017/08/03/ secularists-erase-christianity-from-european-history/).

Sheridan, James , "The Altar of Victory - Paganism's Last Battle”, L'antiquité Classique, Vol. 35, No. 1 (1966): 186-206.

Sherwood, Harriet , “Christianity as Default Is Gone': The Rise of a Non-Christian Europe”, The Guardian, March 21, 2018, accessed on February 13, 2019 (https://www.theguardian.com/world/2018/ $\mathrm{mar} / 21 /$ christianity-non-christian-europe-young-people-surveyreligio).

Sherwood, Harriet, "Muslim Population in Some EU Countries Could Triple, Says Report", The Guardian, November 29, 2017, accessed on February 10, 2019 (https://www.theguardian.com/world/2017/ nov/29/muslim-population-in-europe-could-more-than-double).

Stavrou, David, "No, Europe Isn't Returning to the Bosom of Islam," Haaretz, October 18, 2018, accessed on February 11, 2019 (https:// www.haaretz.com/world-news/europe/no-europe-isn-t-returning-tothe-bosom-of-islam-1.6572926)

Bryce, Viscount, James. The Holy Roman Empire. New York: The Macmillan Company, 1911. 
IJIMS: Indonesian Journal of Islam and Muslim Societies, Volume 9, Number 1, June 2019: 83-110

Wadley, Carma, "O Wadley, Carma, "Ottomans Had a Big Impact on Western Civilization”, Deseret News, August 15, 2002, accessed on February 20, 2019 (https://www.deseretnews.com/article/931174/ Ottomans-had-a-big-impact-on-Western-civilization.html). 